\title{
Spectroscopic and Calorimetric Evaluation of the Biofield Energy Healing Treated Ofloxacin
}

\author{
Gopal Nayak ${ }^{1}$, Mahendra Kumar Trivedi ${ }^{1}$, Alice Branton ${ }^{1}$, Dahryn Trivedi ${ }^{1}$ and Snehasis Jana ${ }^{2 *}$ \\ ${ }^{1}$ Trivedi Global, Inc, Henderson, USA \\ ${ }^{2}$ Trivedi Science Research Laboratory Pvt. Ltd., Bhopal, India
}

Submission: January 25, 2019 Published: February 21, 2019

"Corresponding author: Snehasis Jana, Trivedi Science Research Laboratory Pvt. Ltd., Bhopal, India

\begin{abstract}
Ofloxacin is an antibiotic useful for the treatment of bacterial infections. The aim of this research work was to evaluate the impact of the Trivedi Effect ${ }^{\circledR}$-Consciousness Energy Healing Treatment on the physicochemical properties of ofloxacin using modern analytical techniques. The sample was divided into control and Biofield Energy Treated parts. The control sample did not receive the Biofield Energy Treatment; whereas, the treated part received the Biofield Treatment remotely by a famous Biofield Energy Healer, Gopal Nayak. The PXRD peak intensities and crystallite sizes were significantly altered ranging from $-39.33 \%$ to $127.93 \%$ and $-68.28 \%$ to $21 \%$, respectively; however, the average crystallite size of the treated ofloxacin $(236.59 \mathrm{~nm})$ was decreased by $19.48 \%$ compared with the control sample $(293.83 \mathrm{~nm})$. The particle size values were significantly decreased at $\mathrm{d}_{10}(10.67 \%), \mathrm{d}_{50}(25 \%), \mathrm{d}_{90}(24.4 \%)$, and $\mathrm{D}(4,3)(25.12 \%)$; thus, the specific surface area was significantly increased by $9.8 \%$ in the treated sample compared to the control sample. The latent heat of fusion and the latent heat of decomposition of the treated sample were significantly increased by $11.71 \%$ and $123.52 \%$, respectively compared to the control sample. The total weight loss was significantly decreased by $10.59 \%$; however, the residue amount was significantly increased by $63.29 \%$ in the treated ofloxacin compared with the control sample. The Trivedi Effect ${ }^{\circledR}$-Consciousness Energy Healing Treatment generated a new polymorphic form of ofloxacin which may be more soluble, bioavailable, and be thermally more stable compared to the untreated sample. The treated ofloxacin would be more efficacious against cellulitis, prostatitis, chronic bronchitis, urinary tract infections, infections of the urethra and cervix, pneumonia, infectious diarrhoea, plague, etc.

Keywords: Ofloxacin; The Trivedi Effect ${ }^{\circledR}$, Complementary and alternative medicine; Consciousness Energy Healing Treatment; Crystal size; Particle size; DSC; TGA/DTG
\end{abstract}

\section{Introduction}

Ofloxacin is an antibiotic useful for the treatment of the infections caused by bacteria [1]. It restricts the bacterial cell division by inhibiting its DNA gyrase (type II topoisomerase and topoisomerase IV) [2]. Clinically it is useful for the treatment of bacterial infections, i.e., urethral, urinary tract, and cervix infection, cellulitis, chronic bronchitis, pneumonia, prostatitis, infectious diarrhoea, plague, multidrug-resistant tuberculosis, bacterial infection of the eye and ear, otitis media when there is a hole in the eardrum, etc. $[1,3,4]$. It may inhibit drug metabolizing enzymes and thus increases the theophylline, cyclosporine, warfarin, etc. levels in the blood. The common side effects involved with it are a headache, vomiting, diarrhoea, numbness, tendon rupture, skin rash, psychosis, seizures, etc. [1]. It increases the cardiotoxicity, anticoagulant, and arrhythmias effect when co-administered with drugs such as acenocoumarol, dihydroquinidine, barbiturate, etc. $[4,5]$. The limitation to the ofloxacin is short biological half-life, and its bioavailability is highly dependent on the physiological condition of the gastrointestinal tract. It is highly soluble in acidic media thus precipitates in alkaline media and lose its solubility [4].
The physicochemical properties of a pharmaceutical/ nutraceutical compound play a crucial role in its dissolution, absorption, distribution, and bioavailability in the physiological system [6]. Many scientific research works are going on for the improvement of these parameters of the pharmaceutical/ nutraceutical compounds in the formulations. Surprisingly, the Trivedi Effect ${ }^{\circledR}$-Biofield Energy Healing Treatment has found to be an economical approach for the alteration of the physicochemical properties and bioavailability of the pharmaceutical/nutraceutical compounds [7-10]. The Trivedi Effect ${ }^{\circledR}$ is natural and is the only scientifically proven phenomenon in which a person can harness this inherently intelligent energy and transmit it anywhere on the planet via the possible mediation of neutrinos [11]. Every biological subject possesses a unique electromagnetic field surrounding its body called the "Biofield", which is infinite and para-dimensional. It is generated from the continuous moment of charged particles, cells, blood flow, movement of the heart, etc. in the body.

The "Biofield" based Energy Healing Therapies have been reported with significantly beneficial outcomes against various 
disease conditions [12]. The National Centre for Complementary and Alternative Medicine (NCCAM) and National Institutes of Health (NIH) recommend and included the Energy therapy under the Complementary and Alternative Medicine (CAM) categoryalong with homeopathy, Ayurvedic medicine, naturopathy, traditional Chinese herbs and medicines, massage, acupuncture, acupressure, yoga, meditation, healing touch, Reiki, hypnotherapy, Qi Gong, Tai Chi, deep breathing, special diets, aromatherapy, guided imagery, chiropractic/osteopathic manipulation, movement therapy, Rolfing structural integration, cranial sacral therapy, mindfulness, and applied prayer. Most of the people throughout the globe have accepted the CAM with several advantages $[13,14]$.

The Trivedi Effect ${ }^{\circledR}$-Consciousness Energy Healing Treatment (Biofield Energy Treatment) also has the outstanding capability to alter the characteristic properties of the many living and non-living object(s), i.e., microorganisms, cancer cell line, live stocks, agricultural plants, metals and ceramics, and organic compounds [15-21]. In this experiment, the Trivedi Effect ${ }^{\circledR}{ }_{-}$ Consciousness Energy Healing Treatment on the physicochemical, and thermal properties of ofloxacin was evaluated using powder X-ray diffraction (PXRD), particle size analysis (PSA), differential scanning calorimetry (DSC), and thermogravimetric analysis (TGA)/Differential thermogravimetric analysis (DTG).

\section{Materials and Methods}

\section{Chemicals and Reagents}

All the chemicals and reagents used during the experiment were of the analytical standard. The main chemical used in the experiment was ofloxacin (Sigma Aldrich, USA) and other reagents were purchased from India.

\section{Consciousness Energy Healing treatment Strategies}

The test sample (ofloxacin) was divided into control and the Biofield Energy Treated sample. The control sample did not receive Biofield Energy Treatment. But the control sample was treated with a "sham" healer, who did not have any knowledge about the Biofield Energy Treatment. Similarly, the other part of the sample so called the Biofield Energy Treated sample was received the Consciousness Energy Healing Treatment remotely under standard laboratory conditions for 3 minutes. The Biofield Treatment was provided through the healer's unique energy transmission process by the famous Biofield Energy Healer, Gopal Nayak, India, to one part of the test sample. After the treatment, the Biofield Energy Treated and untreated samples were kept in sealed conditions and characterized using modern analytical techniques.

\section{Characterization}

\section{Powder X-ray Diffraction (PXRD) Analysis}

The XRD analysis of ofloxacin powder sample was executed with the help of Rigaku MiniFlex-II Desktop X-ray diffractometer (Japan) [22,23]. The average size of individual crystallites was calculated from XRD data using the Scherrer's formula (1):

$$
G=k \lambda / \beta \cos \theta
$$

Where $\mathrm{k}$ is the equipment constant (0.94), $\mathrm{G}$ is the crystallite size in $\mathrm{nm}, \lambda$ is the radiation wavelength $(0.154056 \mathrm{~nm}$ for $\mathrm{K} \alpha 1$ emission), $\beta$ is the full-width at half maximum (FWHM), and $\theta$ is the Bragg angle [24].

The $\%$ change in crystallite size $(G)$ of ofloxacin was calculated using the following equation 2 :

$$
\% \text { change in crystallite size }=\frac{G_{\text {Treated }}-G_{\text {Control }}}{G_{\text {Control }}} \times 100
$$

Where $\mathrm{G}_{\text {Control }}$ and $\mathrm{G}_{\text {Treated }}$ are the crystallite size of the control and the Biofield Energy Treated samples, respectively.

\section{Particle Size Analysis (PSA)}

The particle size analysis of ofloxacin powder was executed on Malvern Mastersizer 2000, from the UK using the wet method $[7,8]$. The percent change in particle size (d) for ofloxacin was calculated using the following equation 3 :

$$
\% \text { change in particle size }=\frac{d_{\text {Treated }}-d_{\text {Control }}}{d_{\text {Control }}} \times 100
$$

Where $d_{\text {Control }}$ and $d_{\text {Treated }}$ are the particle size $(\mu \mathrm{m})$ for at below $10 \%$ level $\left(d_{10}\right), 50 \%$ level $\left(d_{50}\right)$, and $90 \%$ level $\left(d_{90}\right)$ of the control and the Biofield Energy Treated samples, respectively.

The percent change in surface area (S) was calculated using the following equation 4 :

$$
\% \text { change in surface area }=\frac{S_{\text {Treated }}-S_{\text {Control }}}{S_{\text {Control }}} \times 100
$$

Where $S_{\text {Control }}$ and $S_{\text {Treated }}$ are the surface area of the control and the Biofield Energy Treated ofloxacin, respectively.

\section{Differential Scanning Calorimetry (DSC)}

The DSC analysis of ofloxacin was performed with the help of DSC Q200, TA instruments. The sample of 1-3 mg was loaded into the aluminium sample pan at a heating rate of $10^{\circ} \mathrm{C} / \mathrm{min}$ from $30^{\circ} \mathrm{C}$ to $350^{\circ} \mathrm{C}[7,8]$. The $\%$ change in melting point (T) was calculated using the following equation 5 :

$$
\% \text { change in melting point }=\frac{T_{\text {Treated }}-T_{\text {Control }}}{T_{\text {Control }}} \times 100
$$

Where, $\mathrm{T}_{\text {Control }}$ and $\mathrm{T}_{\text {Treated }}$ are the melting point of the control and treated samples, respectively.

Percent change in the latent heat of fusion $(\Delta \mathrm{H})$ was calculated using the following equation 6 :

$\%$ change in the latent heat of fusion $=\frac{\Delta H_{\text {Treated }}-\Delta H_{\text {Control }}}{\Delta H_{\text {Control }}} \times 100$

Where, $\Delta \mathrm{H}_{\text {Control }}$ and $\Delta \mathrm{H}_{\text {Treated }}$ are the latent heat of fusion of the control and treated ofloxacin, respectively. 


\section{Thermal Gravimetric Analysis (TGA) / Differential Thermogravimetric Analysis (DTG)}

The TGA/DTG thermograms of ofloxacin samples were obtained with the help of TGA Q50 TA instruments. A sample of 3-5 mg was loaded to the platinum crucible at a heating rate of $10^{\circ} \mathrm{C} / \mathrm{min}$ from $25^{\circ} \mathrm{C}$ to $1000^{\circ} \mathrm{C}[7,8]$. The $\%$ change in weight loss (W) was calculated using the following equation 7 :

$$
\% \text { change in weight loss }=\frac{\left[W_{\text {Treated }}-W_{\text {Control }}\right]}{W_{\text {Control }}} \times 100
$$

Where $\mathrm{W}_{\text {Control }}$ and $\mathrm{W}_{\text {Treated }}$ are the weight loss of the control and the Biofield Energy Treated ofloxacin, respectively.

The $\%$ change in maximum thermal degradation temperature $\left(\mathrm{T}_{\max }\right)(\mathrm{M})$ was calculated using the following equation 8:

$$
\% \text { change in } \mathrm{T}_{\max }=\frac{\left[M_{\text {Treated }}-M_{\text {Control }}\right]}{M_{\text {Control }}} \times 100
$$

Where $\mathrm{M}_{\text {Control }}$ and $\mathrm{M}_{\text {Treated }}$ are the $\mathrm{T}_{\text {max }}$ values of the control and the Biofield Energy Treated ofloxacin, respectively.

\section{Results and Discussion}

\section{Powder X-ray Diffraction (PXRD) Analysis}

The PXRD diffractograms of both the control and Biofield Energy Treated ofloxacin showed sharp and intense peaks (Figure 1). The sharp and intense peaks in the diffractograms indicated that both the samples were crystalline. The control and the treated samples have shown the highest peak intensity at $2 \theta$ equal to $5.99^{\circ}$ and $6.08^{\circ}$, respectively (Table 1 , entry 1 ). The peak intensities of the Biofield Energy Treated sample were significantly altered ranging from $-39.33 \%$ to $127.93 \%$ compared to the control sample. Similarly, the crystallite sizes of the Biofield Energy Treated sample were significantly altered ranging from $-68.28 \%$ to $21 \%$ compared with the control sample. Overall, the average crystallite size of the treated ofloxacin $(236.59 \mathrm{~nm})$ was decreased by $19.48 \%$ compared with the control sample $(293.83 \mathrm{~nm})$.
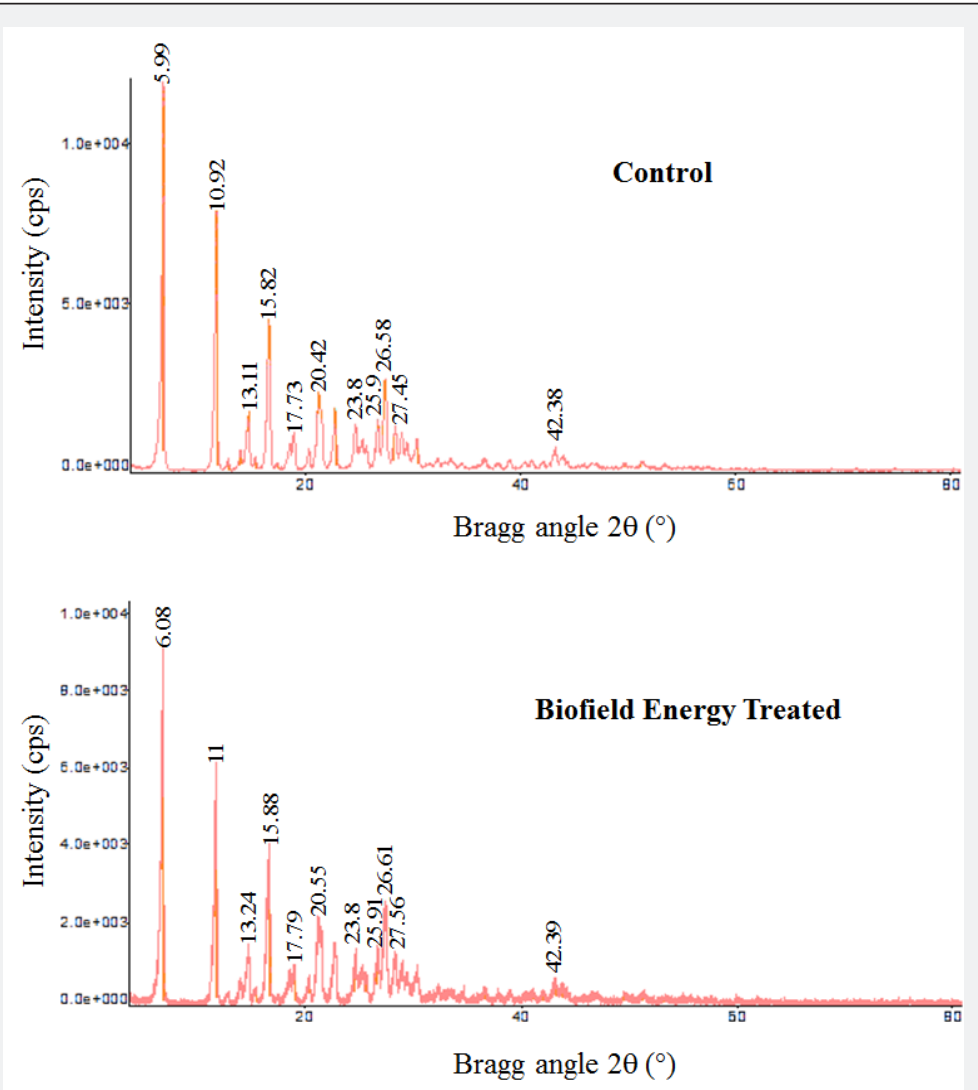

Figure 1: PXRD diffractograms of the control and the Biofield Energy Treated ofloxacin.

Table 1: PXRD data for the control and the Biofield Energy Treated ofloxacin.

\begin{tabular}{|c|c|c|c|c|c|c|c|c|}
\hline \multirow{2}{*}{ Entry No. } & \multicolumn{2}{|c|}{${\text { Bragg angle }\left({ }^{\circ} \mathbf{2 \theta}\right)}$} & \multicolumn{3}{|c|}{ Peak Intensity (\%) } & \multicolumn{3}{c|}{ Crystallite size (G, nm) } \\
\cline { 2 - 10 } & Control & Treated & Control & Treated & \% change & Control & Treated & \% change \\
\hline 1 & 5.99 & 6.08 & 2621 & 2081 & -20.6 & 405 & 295 & -27.16 \\
\hline 2 & 10.92 & 11 & 1674 & 1268 & -24.25 & 317 & 255 & -19.56 \\
\hline 3 & 13.11 & 13.24 & 94 & 108 & 14.89 & 489 & 271 & -44.58 \\
\hline
\end{tabular}




\section{Organic and Medicinal Chemistry International Journal}

\begin{tabular}{|r|c|c|c|c|c|c|c|c|}
\hline 4 & 14.51 & 14.66 & 89 & 54 & -39.33 & 345 & 279 & -19.13 \\
\hline 5 & 15.82 & 15.88 & 1064 & 953 & -10.43 & 252 & 228.6 & -9.29 \\
\hline 6 & 17.73 & 17.79 & 161 & 134 & -16.77 & 237 & 237 & 0 \\
\hline 7 & 18.14 & 18.23 & 248 & 207 & -16.53 & 282 & 243 & -13.83 \\
\hline 8 & 19.51 & 19.59 & 120 & 96 & -20 & 285 & 293 & 2.81 \\
\hline 9 & 20.42 & 20.55 & 790 & 778 & -1.52 & 173 & 168 & -2.89 \\
\hline 10 & 23.8 & 23.8 & 254 & 251 & -1.18 & 278 & 213 & -23.38 \\
\hline 11 & 25.9 & 25.91 & 266 & 274 & 3.01 & 298 & 270 & -9.4 \\
\hline 12 & 26.58 & 26.61 & 656 & 730 & 11.28 & 240 & 213 & -11.25 \\
\hline 13 & 27.45 & 27.56 & 240 & 290 & 20.83 & 439 & 242 & -44.87 \\
\hline 14 & 28.11 & 28.09 & 179 & 408 & 127.93 & 309 & 98 & -68.28 \\
\hline 15 & 35.89 & 35.9 & 81 & 59 & -27.16 & 200 & 242 & 21 \\
\hline 16 & 42.38 & 42.39 & 164 & 123 & -25 & 227 & 218 & -3.96 \\
\hline 17 & 48.77 & 48.75 & 35 & 32 & -8.57 & 309 & 302 & -2.27 \\
\hline 18 & 50.38 & 50.39 & 50 & 48 & -4 & 204 & 191 & -6.37 \\
\hline 19 & Average crystallite size & & & & 293.83 & 236.59 & -19.48 \\
\hline
\end{tabular}

${ }^{a}$ denotes the percentage change in the intensity of the Biofield Energy Treated sample with respect to the control sample; ${ }^{b}$ denotes the percentage change in the crystallite size of the Biofield Energy Treated sample with respect to the control sample.

The crystallite sizes and intensities are interrelated to each other, which indicated the crystal morphology of the Biofield Energy Treated ofloxacin was modified compared to the control sample. The peak intensity of each diffraction face on the crystalline compound changes according to the crystal morphology [25] and alterations in the XRD pattern provide the proof of polymorphic transitions [26,27]. The Consciousness Energy Healing Treatment probably produced a new polymorphic form of ofloxacin via neutrino oscillations [11]. Different polymorphic forms of pharmaceuticals/nutraceutical compounds have significant effects on the drug performance from the original form $[28,29]$. Thus, it can be anticipated that the Biofield Energy Treated ofloxacin would be more efficacious in the pharmaceutical formulations containing ofloxacin. Adenotes the percentage change in the intensity of the Biofield Energy Treated sample with respect to the control sample; bdenotes the percentage change in the crystallite size of the Biofield Energy Treated sample with respect to the control sample.

\section{Particle Size Analysis (PSA)}

Table 2: Particle size distribution of the control and the Biofield Energy Treated ofloxacin.

\begin{tabular}{|c|c|c|c|c|c|}
\hline Parameter & $\mathbf{d}_{\mathbf{1 0}}(\boldsymbol{\mu m})$ & $\mathbf{d}_{\mathbf{5 0}}(\boldsymbol{\mu m})$ & $\mathbf{d}_{\mathbf{9 0}}(\boldsymbol{\mu m})$ & $\mathbf{D}(\mathbf{4 , 3})(\boldsymbol{\mu m})$ & $\mathbf{S S A}\left(\mathbf{m}^{2} / \mathbf{g}\right)$ \\
\hline Control & 2.34 & 21.1 & 208.15 & 70.48 & 1.02 \\
\hline Biofield Treated & 2.09 & 15.82 & 157.36 & 52.77 & 1.12 \\
\hline Percent change* $(\%)$ & -10.67 & -25 & -24.4 & -25.12 & 9.8 \\
\hline
\end{tabular}

$d_{10}, d_{50}$, and $d_{90}$ : particle diameter corresponding to $10 \%, 50 \%$, and $90 \%$ of the cumulative distribution, $D(4,3)$ : the average mass-volume diameter, and SSA: the specific surface area. *denotes the percentage change in the Particle size distribution of the Biofield Energy Treated sample with respect to the control sample.

The particle size and surface area analysis data are presented in Table 2. The particle size values of the control sample at $d_{10}$, $\mathrm{d}_{50}, \mathrm{~d}_{90}$, and D $(4,3)$ were $2.34 \mu \mathrm{m}, 21.10 \mu \mathrm{m}, 208.15 \mu \mathrm{m}$, and 70.48 $\mu \mathrm{m}$, respectively. Similarly, the particle sizes of the treated sample at $\mathrm{d}_{10}, \mathrm{~d}_{50}, \mathrm{~d}_{90}$, and $\mathrm{D}(4,3)$ were $2.09 \mu \mathrm{m}, 15.82 \mu \mathrm{m}, 157.36 \mu \mathrm{m}$, and $52.77 \mu \mathrm{m}$, respectively. The particle size values in the Biofield Energy Treated ofloxacin were significantly decreased at $\mathrm{d}_{10}, \mathrm{~d}_{50}$, d 90 , and $D(4,3)$ by $10.67 \%, 25 \%, 24.4 \%$, and $25.12 \%$, respectively, compared to the control sample. Thus, the specific surface area of the treated sample $\left(1.02 \mathrm{~m}^{2} / \mathrm{g}\right)$ was significantly increased by $9.8 \%$ compared with the control sample $\left(0.1 .12 \mathrm{~m}^{2} / \mathrm{g}\right)$. Hence, the Trivedi Effect ${ }^{\circledR}$-Consciousness Energy Healing Treatment assumed to be having a significant effect on the reduction of the particle sizes of ofloxacin powder. Reduction of the particle size increases the surface area and improve the solubility, dissolution rate, and bioavailability in the physiological system $[6,30]$. The solubility profile of ofloxacin in water, alcohol, dichloromethane, methyl alcohol, and chloroform are poor [31]. Thus, the Trivedi Effect ${ }^{\circledR}$ Consciousness Energy Healing Treated ofloxacin would be more soluble and bioavailable compared with the untreated sample.

\section{Differential Scanning Calorimetry (DSC) Analysis}

DSC data of both control and the Biofield Energy Treated ofloxacin samples are presented in (Table 3). The control and the Biofield Energy Treated sample showed a sharp endothermic peak at $276.61^{\circ} \mathrm{C}$ and $277.11^{\circ} \mathrm{C}$, respectively in the thermogram. 
Similarly, the control and the treated samples showed exothermic peaks at $330.52^{\circ} \mathrm{C}$ and $331.72^{\circ} \mathrm{C}$, respectively (Figure 2). The thermogram pattern and melting point thoroughly matched to the reported data [32]. The melting point and decomposition samples of ofloxacin. temperature of the Biofield Energy Treated sample were slightly increased by $0.18 \%$ and $0.36 \%$, respectively compared with the control sample (Table 3).

Table 3: DSC data for both control and the Biofield Energy Treated

\begin{tabular}{|c|c|c|c|c|}
\hline \multirow{2}{*}{ Sample } & \multirow{2}{*}{ Melting Temp $\left({ }^{\circ} \mathbf{C}\right)$} & \multirow{2}{*}{ Decomposition Temp $\left({ }^{\circ} \mathbf{C}\right)$} & \multicolumn{2}{|c|}{$\Delta \mathbf{H}(\mathbf{J} / \mathbf{g})$} \\
\cline { 3 - 5 } & & & Melting & Decomposition \\
\hline Control Sample & 276.61 & 330.52 & 102.5 & 73.33 \\
\hline Biofield Energy Treated & 277.11 & 331.72 & 114.5 & 74.5 \\
\hline \% Change* & 0.18 & 0.36 & 11.71 & 123.52 \\
\hline
\end{tabular}

$\Delta \mathrm{H}$ : Latent heat of fusion/decomposition, *denotes the percentage change of the Biofield Energy Treated ofloxacin with respect to the control sample.

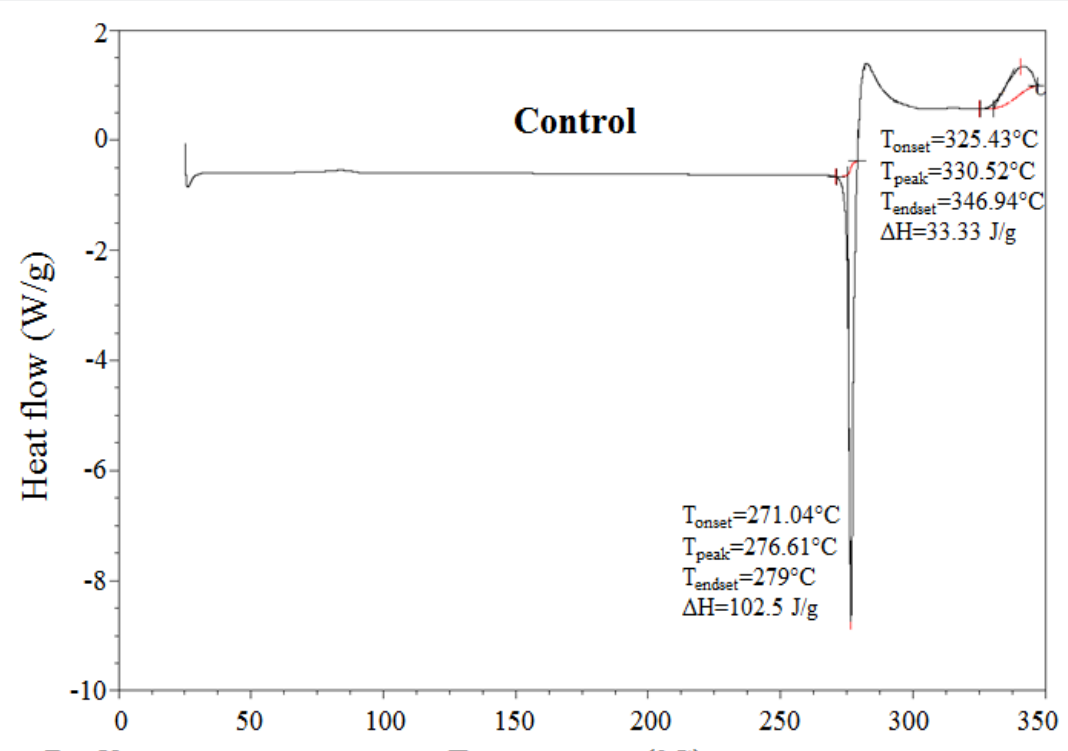

Exo Up Temperature $\left({ }^{\circ} \mathrm{C}\right)$

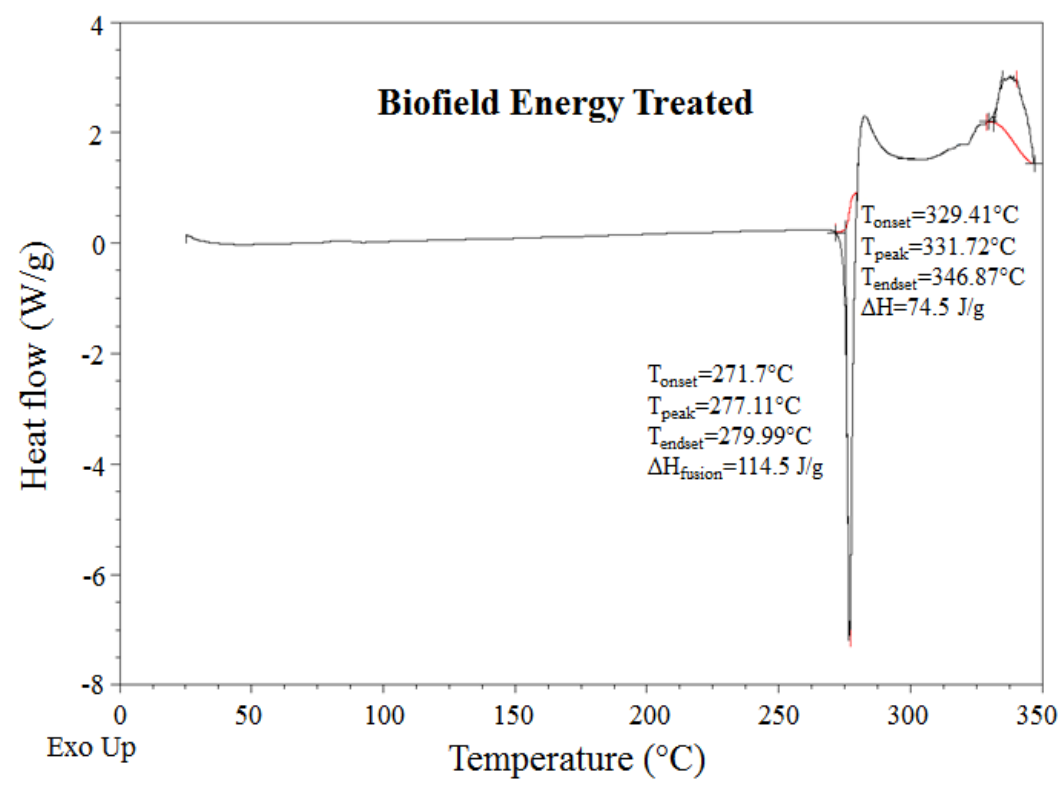

Figure 2: DSC thermograms of the control and the Biofield Energy Treated ofloxacin. 
The latent heat of fusion $\left(\Delta \mathrm{H}_{\text {fusion }}\right)$ and the latent heat of decomposition $\left(\Delta \mathrm{H}_{\text {decomposition }}\right)$ of the Biofield Energy Treated sample were significantly increased by $11.71 \%$ and $123.52 \%$ compared with the control sample (Table 3). The change in the latent heat of fusion and decomposition can be attributed to the disrupted molecule chains and the molecular structure. Thus, it can be predicted that the Trivedi Effect ${ }^{\circledR}$ might be responsible for the disruption of the molecular chains and crystal structure of ofloxacin which the cause of improved thermal stability of the treated sample was compared with the control sample.

\section{Thermal Gravimetric Analysis (TGA) / Differential Thermogravimetric Analysis (DTG)}

The TGA thermograms of both the samples displayed one step of thermal degradation (Figure 3). The total weight loss in the treated ofloxacin was significantly decreased by $10.59 \%$ compared to the control sample (Table 4). However, the residue amount was significantly increased by $63.29 \%$ in the Biofield Energy Treated ofloxacin compared with the control sample (Table 4).
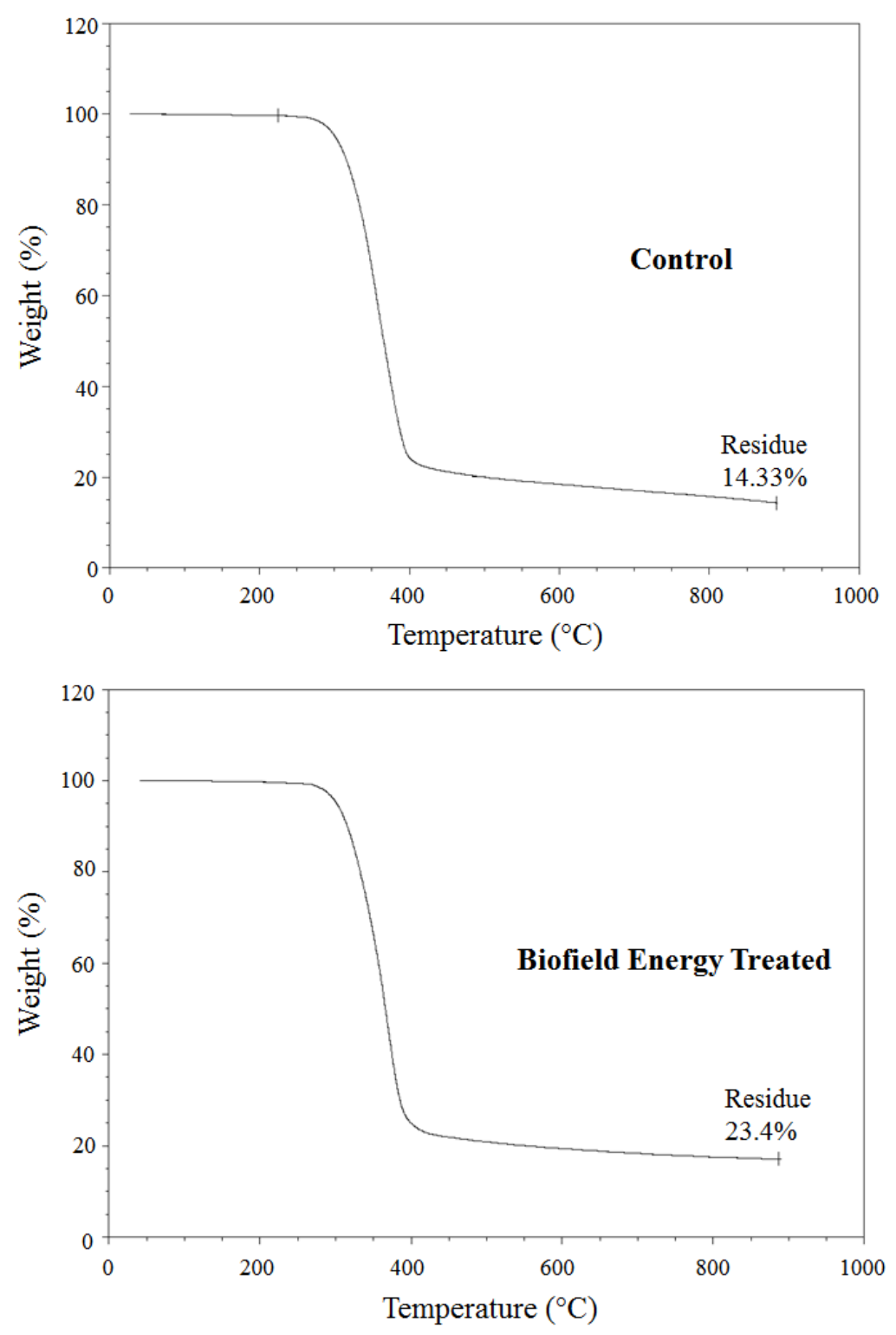

Figure 3: TGA thermograms of the control and the Biofield Energy Treated ofloxacin.

Similarly, the DTG thermograms of both the sample showed only one peak (Figure 4). The maximum thermal degradation temperature $\left(\mathrm{T}_{\max }\right)$ of the treated sample was increased by $2.58 \%$ compared with the control sample (Table 4). Overall, TGA/
DTG revealed that the thermal stability of the Trivedi Effect ${ }^{\circledR}$ Consciousness Energy Healing Treated ofloxacin was significantly improved compared with the control sample. 

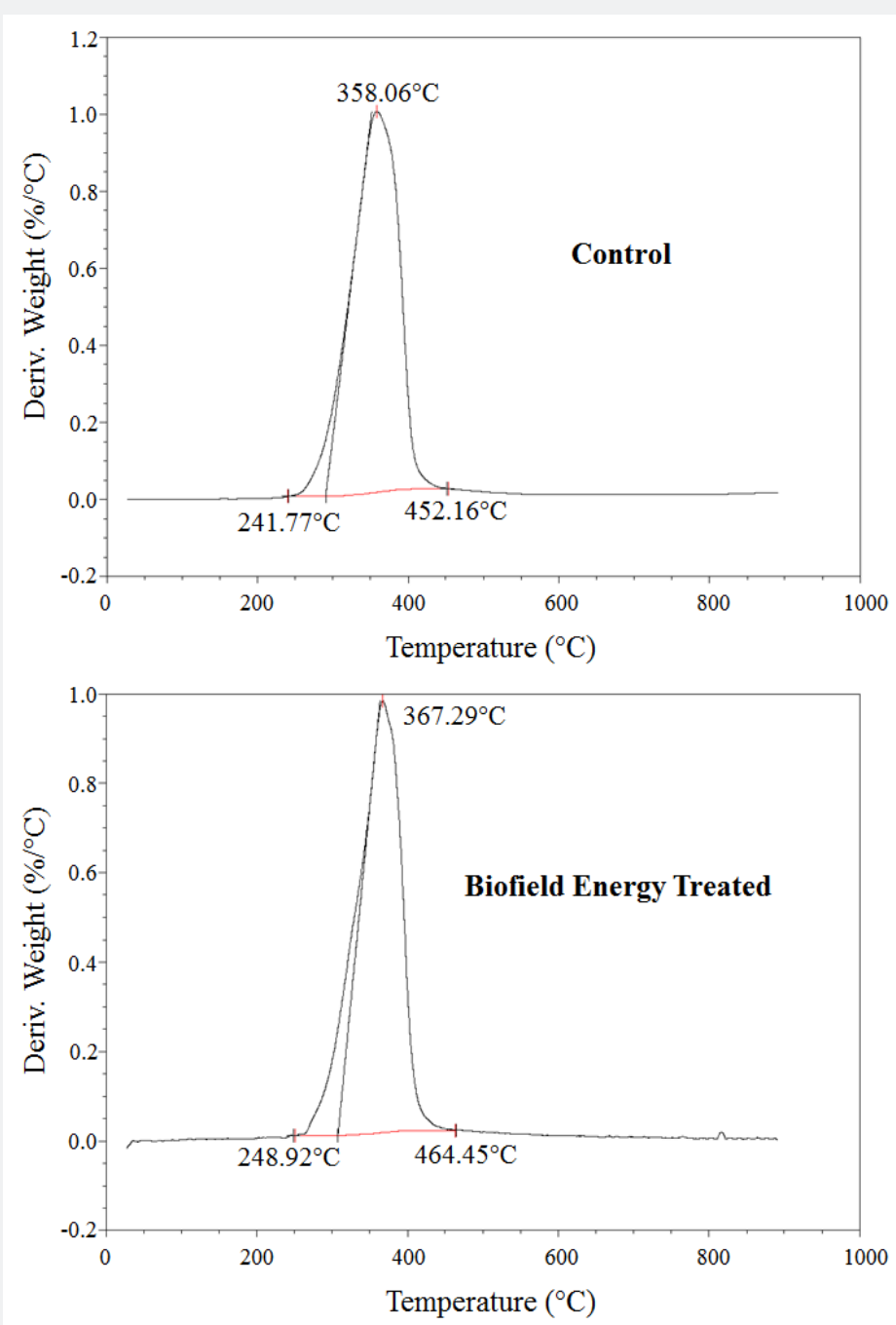

Figure 4: DTG thermograms of the control and the Biofield Energy Treated ofloxacin.

Table 4: TGA/DTG data of the control and the Biofield Energy Treated samples of ofloxacin.

\begin{tabular}{|c|c|c|c|}
\hline \multirow{2}{*}{ Sample } & \multicolumn{2}{|c|}{ TGA } & DTG \\
\cline { 2 - 4 } & Total weight loss (\%) & Residue \% & T $\left._{\text {max }}{ }^{\circ}{ }^{\circ} \mathbf{C}\right)$ \\
\hline Control & 85.67 & 14.33 & 358.06 \\
\hline Biofield Energy Treated & 76.6 & 23.4 & 367.29 \\
\hline \% Change* & -10.59 & 63.29 & 2.58 \\
\hline
\end{tabular}

*denotes the percentage change of the Biofield Energy Treated sample with respect to the control sample, $\mathrm{T}_{\max }=$ the temperature at which maximum weight loss takes place in TG or peak temperature in DTG.

\section{Conclusion}

The physicochemical and thermal properties of the Trivedi Effect ${ }^{\circledR}$-Consciousness Energy Healing Treated ofloxacin were evaluated compared to the control sample. The PXRD peak intensities and crystallite sizes were significantly altered ranging from $-39.33 \%$ to $127.93 \%$ and $-68.28 \%$ to $21 \%$, respectively; however, the average crystallite size of the Biofield Energy Treated ofloxacin was decreased by $19.48 \%$ compared with the control sample. The particle size values were significantly decreased at $d_{10}(10.67 \%), d_{50}$ (25\%), $d_{90}(24.4 \%)$, and D $(4,3)(25.12 \%)$; thus, the specific surface area was significantly increased by $9.8 \%$ in the Biofield Energy Treated sample compared to the control sample. The latent heat of fusion and the latent heat of decomposition of the Biofield Energy Treated ofloxacin were significantly increased by $11.71 \%$ and $123.52 \%$, respectively compared to the control sample. The total weight loss was significantly decreased by 10.59\%; however, the residue amount was significantly increased by $63.29 \%$ in the Biofield Energy Treated sample compared with 
the control sample. The Trivedi Effect ${ }^{\circledR}$-Consciousness Energy Healing Treatment generated a new polymorphic form of ofloxacin which may be more soluble, bioavailable, and be thermally more stable compared to the untreated sample. The Consciousness Energy Healing Treated ofloxacin would be very useful for the designing of better pharmaceutical formulations. The treated ofloxacin may offer better therapeutic response against infectious diarrhoea, cellulitis, pneumonia, chronic bronchitis, urinary tract infections, infections of the urethra and cervix (i.e., gonorrhoea), prostatitis, multidrug-resistant tuberculosis, plague, bacterial infection of the eye and ear, etc.

\section{Acknowledgement}

The authors are grateful to Central Leather Research Institute, SIPRA Lab. Ltd., Trivedi Science, Trivedi Global, Inc., Trivedi Testimonials, and Trivedi Master Wellness for their assistance and support during this work.

\section{References}

1. Ofloxacin (2018) The American Society of Health-System Pharmacists.

2. Drlica K, Zhao X (1997) DNA gyrase, topoisomerase IV, and the 4-quinolones. Microbiol Mol Biol Rev 61(3): 377-392.

3. British national formulary (2015) $\left(6^{\text {th }}\right.$ Edn.), British Medical Association 409: 757-782.

4. Monk JP, Campoli-Richards DM (1987) Ofloxacin. A review of its antibacterial activity, pharmacokinetic properties and therapeutic use. Drugs 33(4): 346-391.

5. Van der Linden PD, Sturkenboom MC, Herings RM, Leufkens HM, Rowlands S, et al. (2003) Increased risk of achilles tendon rupture with quinolone antibacterial use, especially in elderly patients taking oral corticosteroids. Arch Intern Med 163(15): 1801-1807.

6. Chereson R (2009) Bioavailability, bioequivalence, and drug selection. In: Makoid CM, Vuchetich PJ, Banakar UV (Eds) Basic pharmacokinetics ( $1^{\text {st }}$ Edn) Pharmaceutical Press, London.

7. Branton A, Trivedi MK, Trivedi D, Nayak G (2018) Evaluation of the physicochemical and thermal properties of the biofield energy healing treated ofloxacin. J Pharm Pharmaceutics 5: 80-87.

8. Nayak G, Trivedi MK, Branton A, Trivedi D, Jana S (2018) The energy of consciousness healing treatment: Impact on physicochemical and thermal properties of l-tryptophan. Journal of Food Science and Technology 5: 084-094.

9. Branton A, Jana S (2017) The influence of energy of consciousness healing treatment on low bioavailable resveratrol in male Sprague Dawley rats. International Journal of Clinical and Developmental Anatomy 3(3): 9-15.

10. Branton A, Jana S (2017) The use of novel and unique biofield energy healing treatment for the improvement of poorly bioavailable compound, berberine in male Sprague Dawley rats. American Journal of Clinical and Experimental Medicine 5(4): 138-144.

11. Trivedi MK, Mohan TRR (2016) Biofield energy signals, energy transmission and neutrinos. American Journal of Modern Physics 5(6): 172-176.

12. Rubik B, Muehsam D, Hammerschlag R, Jain S (2015) Biofield science and healing: history, terminology, and concepts. Glob Adv Health Med 4: 8-14.

13. Barnes PM, Bloom B, Nahin RL (2008) Complementary and alternative medicine use among adults and children: United States, 2007. Natl Health Stat Report 12: 1-23.
14. Koithan M (2009) Introducing complementary and alternative therapies J Nurse Pract 5: 18-20.

15. Trivedi MK, Branton A, Trivedi D, Nayak G, Mondal SC, et al. (2015) Antimicrobial sensitivity, biochemical characteristics and biotyping of Staphylococcus saprophyticus: An impact of biofield energy treatment. J Women's Health Care 4(6): 271.

16. Trivedi MK, Patil S, Shettigar H, Mondal SC, Jana S (2015) The potential impact of biofield treatment on human brain tumor cells: A time-lapse video microscopy. J Integr Oncol 4(3): 141.

17. Trivedi MK, Branton A, Trivedi D, Nayak G, Mondal SC, et al. (2015) Effect of biofield treated energized water on the growth and health status in chicken (Gallus gallus domesticus). Poult Fish Wildl Sci 3: 140.

18. Trivedi MK, Branton A, Trivedi D, Nayak G, Mondal SC, Jana S (2015) Evaluation of plant growth regulator, immunity and DNA fingerprinting of biofield energy treated mustard seeds (Brassica juncea). Agriculture, Forestry and Fisheries 4(6): 269-274.

19. Trivedi MK, Tallapragada RM (2008) A transcendental to changing metal powder characteristics. Metal Powder Report 63(9): 22-28.

20. Trivedi MK, Nayak G, Patil S, Tallapragada RM, Latiyal O (2015) Studies of the atomic and crystalline characteristics of ceramic oxide nano powders after bio field treatment. Ind Eng Manage 4: 161.

21. Trivedi MK, Branton A, Trivedi D, Nayak G, Panda P, Jana S (2016) Mass spectrometric analysis of isotopic abundance ratio in biofield energy treated thymol. Frontiers in Applied Chemistry 1(1): 1-8.

22. Desktop X-ray Diffractometer "MiniFlex+". The Rigaku Journal 14: 2936; 1997.

23. Zhang T, Paluch K, Scalabrino G, Frankish N, Healy AM, et al. (2015) Molecular structure studies of (1S,2S)-2-benzyl-2,3-dihydro-2(1Hinden-2-yl)-1H-inden-1-ol. J Mol Struct 1083: 286-299.

24. Langford JI, Wilson AJC (1978) Scherrer after sixty years: A survey and some new results in the determination of crystallite size. J Appl Cryst 11(2): 102-113.

25. Inoue M, Hirasawa I (2013) The relationship between crystal morphology and XRD peak intensity on $\mathrm{CaSO}_{4} \cdot 2 \mathrm{H}_{2} \mathrm{O}$. J Crystal Growth 380: 169-175.

26. Raza K, Kumar P, Ratan S, Malik R, Arora S (2014) Polymorphism: The phenomenon affecting the performance of drugs. SOJ Pharm Pharm Sci 1(2): 10.

27. Brittain HG (2009) Polymorphism in pharmaceutical solids in Drugs and Pharmaceutical Sciences. ( $\left.2^{\text {nd }} e d n\right)$. Informa Healthcare USA, New York.

28. Censi R, Martino PD (2015) Polymorph Impact on the Bioavailability and Stability of Poorly Soluble Drugs. Molecules 20(10): 18759-18776.

29. Blagden N, de Matas M, Gavan PT, York P (2007) Crystal engineering of active pharmaceutical ingredients to improve solubility and dissolution rates. Adv Drug Deliv Rev 59(7): 617-630.

30. Zhao Z, Xie M, Li Y, Chen A, Li G, Zhang J, et al. (2015) Formation of curcumin nanoparticles via solution-enhanced dispersion by supercritical $\mathrm{CO}_{2}$. Int J Nanomedicine 10: 3171-3181.

31. Al-Omar MA. (2009) Brittain editor: Profiles of Drug Substances, Excipients, and Related Methodology. Burlington: Academic Press, pp. 265-298.

32. Gulkari VD, Bakhle SS, Yelane LS (2016) Development and evaluation of ofloxacin floating tablets using natural polymer: Sterculia foetida linn. Gum. Int J Pharm Pharm Sci 8(0035): 356-360.

33. Zhao Z, Xie M, Li Y, Chen A, Li G, Zhang J, et al. (2015) Formation of curcumin nanoparticles via solution-enhanced dispersion by supercritical C02. Int J Nanomedicine 10: 3171-3181. 
(C) Commons Attribution 4.0 License

OI: 10.19080/OMCIJ.2019.08.555731

\section{Your next submission with Juniper Publishers will reach you the below assets}

- Quality Editorial service

- Swift Peer Review

- Reprints availability

- E-prints Service

- Manuscript Podcast for convenient understanding

- Global attainment for your research

- Manuscript accessibility in different formats

( Pdf, E-pub, Full Text, Audio)

- Unceasing customer service

Track the below URL for one-step submission https://juniperpublishers.com/online-submission.php 